\title{
A Comparative Study of National Humiliation Education in China and Foreign Countries and Enlightenment to the Work of Chinese Universities
}

\author{
Yuan Yuan*
}

\author{
School of Marxism, Northwestern Polytechnical University \\ *Corresponding author.Email: yuanyuan@nwpu.edu.cn
}

\begin{abstract}
National humiliation education is an indispensable part of patriotism education, and it is very important to carry out national humiliation education among young college students. By analysing the problems and causes of the current national humiliation education in colleges and universities, and learning from the effective practices of other countries, we can put forward corresponding policies and suggestions, which will help strengthen and improve the ideological and political work in colleges and universities in the new era.
\end{abstract}

Keywords: Comparative study, College students, National humiliation education.

\section{SIGNIFICANCE OF STRENGTHENING NATIONAL HUMILIATION EDUCATION FOR COLLEGE STUDENTS IN THE NEW ERA}

The national humiliation education is to educate the people (especially the youth) of a country or a nation by using the historical facts of damage and humiliation they have suffered in the history of development. From the early days of the founding of the Communist Party of China (CPC) to its subsequent development, the CPC has always attached great importance to the special function of national humiliation education [1], which is to "arouse the national anger by building up the national humiliation and shape the national soul by washing away the national humiliation". As Socialism with Chinese Characteristics entering a new era, in the historical process of realizing the "Two Centenary" Goals and the great dream of national rejuvenation, and in the face of the complicated international and domestic situation and the test of long-term governance, the national humiliation education should not be weakened but be strengthened.

\subsection{Education of National Humiliation is an Important Part of Patriotism Education}

Outline for the Implementation of Patriotism Education in the New Era points out that the resources of patriotism education contained in major commemorative days and major historical events should be fully explored, and during the anniversary of the victory of the Chinese People's Anti-Japanese War, the Martyrs' Day, and the national memorial day for the victims of the Nanjing Massacre, activities such as public memorial ceremonies, monument visits, and sacrifice to the tomb of the martyrs should be carefully organized to stimulate patriotic enthusiasm and coalesce the power of advancement [2]. It can be seen that in order to carry out patriotism education, we should not only guide college students to sing the main theme of patriotism and praise the great achievements made by the Communist Party of China in leading its people in socialist revolution and construction, but also face up to the historical facts of China's poverty, weakness and humiliation in modern times, so as to help college students further establish national consciousness and enhance patriotic feelings.

\subsection{Education of National Humiliation is an Effective Tool to Enhance the National Sense of Worry}

The sense of worry and danger is an indispensable psychological state for Chinese people at all times. Looking back on history, Marx once profoundly pointed out that "a large country with a population of almost one third of humanity, regardless of the current situation and 
resting on the status quo, is artificially isolated from the outside world and therefore tries to deceive itself with the illusion of the perfection of the heavenly dynasty. Such an empire is destined to be defeated in a duel to the death" [3]. For the contemporary Post-00 college students, their parents and them have basically grown up and lived for a long time in the peace era, whose awareness of national humiliation is getting weaker and weaker. Therefore, as the builders and successors of Socialism with Chinese Characteristics, it is imperative to educate contemporary college students about national humiliation, and it is urgent to educate and remind them to remember history, enhance their sense of worry and national defense, and strengthen their struggle spirit and skills.

\subsection{Education of National Humiliation is a Necessary Means to Strengthen the Sense of Chinese National Community}

Education of national humiliation is one of the important contents of education on national unity and progress, and its effectiveness is related to national independence, national wealth and strength, and the realization of Chinese Dream. In the impression of Western countries, China before modern times "was not a real country, but a myth, a dream that hid the desires and horrors of Westerners". Through in-depth education of national humiliation, it is of great significance for the education on the sense of Chinese national community and the work on national unity and progress, which is helpful to unite all ethnic groups to form a psychological consensus for making common cause, to consolidate and develop the broadest possible patriotic united front, to constantly enhance the identity of the great motherland, Chinese nation, Chinese culture, Communist Party of China, and Socialism with Chinese Characteristics, and to help cultivate the national spirit and strengthen the national cohesion, so that the tradition of all ethnic groups sharing the same breath and a common destiny with one heart is passed on from generation to generation.

\section{PROBLEMS IN THE CURRENT NATIONAL HUMILIATION EDUCATION FOR COLLEGE STUDENTS}

Since the reform and opening up, Chinese people's concept of national humiliation is increasingly weakened while they fully enjoy the great changes brought by the gradual improvement of material level to their life. In colleges and universities, the main performance is:

\subsection{The National Humiliation Awareness of College Students Varies}

According to the questionnaire survey, contemporary college students have a positive attitude towards the inclusion of the historical facts of humiliation suffered in China's history into the category of national humiliation, but some of them still show a certain degree of confusion and don't know how to view the international conflicts and contradictions under the new situation and at the new stage. In addition, although Chinese government has officially set September 3 every year as the anniversary of the Victory of Chinese People's Anti-Japanese War and December 13 every year as the National Memorial Day for the Victims of the Nanjing Massacre, $14.2 \%$ of the surveyed students still chose the answer "I don't care" to the question "Do you think it is necessary to set up a unified national day to commemorate national humiliation?"

\subsection{The Effectiveness and Relevance of National Humiliation Education in Colleges and Universities are not Obvious}

According to this survey, $62.7 \%, 24.3 \%$ and $3.8 \%$ of the respondents think that the status of national humiliation education for college students is "average", "poor" and "very poor" respectively. This phenomenon shows that some colleges and universities have not carefully designed the curriculum of national humiliation education according to the cognitive level and thinking characteristics of college students, and most of the current national humiliation education being carried out lacks relevance, or is not precisely targeted at the characteristics of college students. Therefore, it can be seen that there is an obvious lack of position in the development of national humiliation education in higher education institutions that undertake the responsibility of talent cultivation.

\subsection{The Participation of College Students in National Humiliation Education Activities is not Active}

According to this survey, $82.7 \%$ of the respondents said that they had not participated in the national humiliation education activities organized by their universities during their school days, and the reason was that these activities were too formal and had no practical significance. They are hardly attracted by the traditional national humiliation education activities that are not well designed, which may even be counterproductive due to the intensification of rebelliousness. 


\subsection{There are Various Reasons for the Above Phenomena, which can be Summarized in the Following Four Aspects}

\subsubsection{As one of the Main Bodies of Education, Schools do not Pay Enough Attention to National Humiliation Education}

In the current national humiliation education in China, there are many problems such as insufficient attention, insufficient investment, tight funding, weak propaganda and lack of attraction, all of which directly affect the effect of national humiliation education. Some even go so far as to arbitrarily delete the content about national humiliation from the teaching materials for history education for young people. We must strongly condemn the acts of other governments to distort and deny history, and first use the historical facts of national humiliation to educate our young generation, so that they can firstly have a correct understanding of the national humiliation in our history, otherwise the purpose of national humiliation education cannot be achieved at all.

\subsubsection{As the Object of Education, the Awareness of National Humiliation among College Students has been Diluted}

It has been 180 years since the British invasion of China in 1840, nearly 75 years since the defeat and surrender of Japan in 1945, at least 40 years since the war to resist U.S. aggression and aid Korea, the counterattack in self-defense on the Sino-Indian border and the counterattack in self-defense against Vietnam, and more than 20 years since the bombing of our embassy in Yugoslavia and the collision between China and the United States in the South China Sea. With the passage of time, people who have been living in peace for a long time are gradually forgetting the historical struggles against aggression and invasion, and their memory of the incidents that other countries provoked China's sovereignty and territorial integrity has gradually blurred. Some researches show that the utilitarian tendency of contemporary college students in campus life and study is becoming more and more obvious, and there is a group of so-called "sophisticated egoists", who tend to attach great importance to academic achievements, honors and material benefits related to their personal development, and are happy to manage interpersonal relationship closely related to the above aspects. However, they are indifferent to other public welfare and collective affairs that seems unrelated or not closely related to their personal development, and hardly involved in any campus activities, let alone national humiliation education.

\subsubsection{As a Carrier of Education, People and Historical Relics of National Humiliation Events are Increasingly Scarce}

It has been 71 years since the founding of People's Republic of China, and one of the most intuitive ways to educate people who have not experienced the history of aggression against their motherland is through the narratives of people who have lived through this period, and through on-site education and research of historical materials based on relevant historical sites. However, as time goes by, people's memory of national humiliation events and their awareness of national humiliation will not only gradually fade away, but the vehicles for national humiliation education (including people and objects) will also become increasingly scarce due to natural death and wear and tear. As material evidence of the invasion and humiliation suffered by the country in the past, historical sites are of great value for research and education, but these sites have been damaged in different ways over the years, including natural factors such as wind, rain and sunlight, and more importantly, human factors such as demolition and relocation. In addition, those who have experienced the humiliating history of Old China are the important witnesses of the national humiliation and family suffering, but most of them who suffered during those years have already reached their old age, for example, there are only less than 80 survivors of the Nanjing Massacre and only 3 survivors of the Pingdingshan Massacre in Fushun.

\subsubsection{The Environment for National Humiliation Education is Becoming Increasingly Complex and Disturbing.}

The first factor is the interference of peaceful evolution and militarism. In the context of economic globalization, some Western countries exert a subtle influence on teenagers who are not yet mentally mature, having a great impact on college students whose world view and life view are in the initial stage of establishment. The second factor is the lack of social humiliation culture. With the further development of market economy, the value orientation with interest as the core has greatly impacted on the traditional value orientation of justice over profit in China, which has led to the confusion of value judgment in the whole society. The lack of social humiliation culture has made many students unable to distinguish between beauty and ugliness, good and evil, as well as right and wrong in terms of value, honor and humiliation. The social chaos caused by the lack of social humiliation culture has a certain negative impact on the implementation of national humiliation education for college students. Furthermore, influenced by some traditional Chinese concepts such as "reporting good news but not bad news to parents and keeping family humiliation as secrets", we cannot correctly deal with the relationship between 
national honor education and national humiliation education, and some groups and individuals have concerns and even intentionally weaken the national humiliation education while unilaterally strengthen the national honor education.

\section{PRACTICE AND ENLIGHTENMENT OF NATIONAL HUMILIATION EDUCATION IN SOME COUNTRIES}

Carrying out national humiliation education has become a common phenomenon in countries around the world in order to educate their nationals, including visiting important historical sites and relics, reviewing historical facts, remembering the dead, and holding national public ceremonies [4]. The specific methods are as follows:

\subsection{Education on National Humiliation through Important Historical Sites}

Every year, the Israeli government and its local departments will organize several visits to the famous "Wailing Wall" at the Holy Temple in Jerusalem to recall the injustices suffered by the Jewish people and the tragic fate of their ancestors. Besides, in 1962, the United States built a memorial hall on the southeast corner of Ford Island named after USS Arizona, the battleship with the largest number of fatalities in this incident, in order to remind citizens of the historical lessons of Pearl Harbour.

\subsection{Education on National Humiliation through History}

In history, Finland has been colonized by powerful countries for more than 700 years. Every year, on major anniversaries such as National Independence Day on December 6 and Flag Day on June 4, Finland government will organize a variety of commemorative activities to strengthen people's sense of worry and their concept of national interests first. During the Kosovo War, patriotic songs and feature films about wars against aggression in the Second World War were broadcasted daily on the FRY Television Station to boost the morale of the army and the people and inspire them to participate in the war.

\subsection{Education on National Humiliation through Remembrance of the Dead}

As we all know, Poland was persecuted by Nazis in the history. On the Day of the Dead, which falls on November 1 every year, the whole country will sound the siren for two minutes, and people will not only go to the cemetery to pay their respects, but also hold a sorrowful memorial service in Auschwitz. After the 9 11 Incident, tens of thousands of relatives of victims and government officials in the United States will gather at the former site of the World Trade Centre in New York to hold large-scale memorial activities.

\subsection{Education on National Humiliation through National Rituals}

In places such as Auschwitz in Poland, Pearl Harbour in the United States, Hiroshima and Nagasaki in Japan, and Jerusalem in Israel, grand national memorial ceremonies have been held every year. Generally, the specifications are relatively high, because heads of state, presidents of parliament, and leaders of major parties are usually present to lay baskets and wreaths. Meanwhile, many countries have also identified the sites of public memorial ceremonies as national educational bases or conservation units, thus highlighting the importance of the day. In a word, national ceremonies have become an important means of civic education in various countries.

\section{SUGGESTIONS FOR STRENGTHENING NATIONAL HUMILIATION EDUCATION FOR COLLEGE STUDENTS IN THE NEW ERA}

National humiliation education is a process of reconstructing the contemporary value of the Chinese traditional moral culture in the new situation by taking the Chinese traditional moral culture as the basis, so as to make Chinese traditional humiliation culture be inherited and developed continuously [5]. Contemporary college students are responsible for the historical mission of realizing the "Two Centenary Goals" and are also an important force in realizing the Chinese Dream of great rejuvenation of the Chinese nation. Whether their ideals and beliefs are firm and whether their patriotic feelings are deep will directly affect the success of the cause of Socialism with Chinese Characteristics. Learning from the effective practices of national humiliation education in other countries can provide useful reference for us to strengthen national humiliation education for college students in the new era.

\subsection{Attach Great Importance and Strengthen Supervision and Assessment}

National humiliation education is an organic part of patriotism education as well as ideological and political education based on its irreplaceable and unique role. Education administrative departments at all levels and colleges and universities should constantly raise the importance of national humiliation education, treat it as an important part for patriotism education of citizens and for ideological and political education of college students, make careful arrangement and deployment, incorporate it into the task list of Party organizations at 
all levels for comprehensive strict governance, carry out supervision and inspection, and grasp the implementation of work. The national humiliation education should be included in the propaganda and ideological work plan, spiritual civilization work plan, social practice system of college students and training course outline of Party school and Youth League school as a compulsory option of patriotism education, and should be integrated into the whole process of education.

\subsection{Change the Mode of Thinking and View the Historical Facts Dialectically}

Historically, Chinese nation has created the glorious Chinese civilization, while it is an indisputable fact that it has been repeatedly invaded by foreign enemies since modern times. The education for young college students should compare the positive and negative historical facts, not only to make clear the historical achievements and cultivate a sense of national pride and identity, but also dare to talk about humiliation and not deliberately avoid it; not only to make students empathize with the humiliation of our country being invaded and the people being bullied, but also to supplement it with national honour education at the right time, using the glorious achievements of our country and nation in the process of historical development to inspire the national self-confidence of the education target, so as to make them be confident but not arrogant, to know humiliation but not inferiority, and to shoulder the historical mission of realizing the Chinese Dream of great rejuvenation of the Chinese nation with modesty and prudence, but not too humble or overbearing.

\subsection{Carefully Design and Solidify the Education Carrier}

As a kind of ritual education, national humiliation education, like flag-raising ceremonies, commendation meetings, festival days and other educational methods, needs to have relatively stable educational channels, carriers and forms, so as to maintain the seriousness of national humiliation education on the one hand and avoid the randomness brought by improvisation or patchwork combinations to the education targets on the other hand, which also helps to ensure that a long-term mechanism for national humiliation education can be established, and that it can be conducted at a fixed time each year in a relatively regular process. The education of national humiliation can be incorporated in various forms such as the "First Class of Admission" and special Party Day Activities, and can also be solidified into branded student education activities such as lectures on the deeds of typical representative figures and memorials of martyrs.

\subsection{Multi-measures to Attract Students and Teachers to Participate in}

The target group of national humiliation education is not only college students but also faculty and staff of universities, because educators have to be educated first. Therefore, the contents and methods of education should be carefully designed according to mode of thinking and psychological characteristics of teachers and students in colleges and universities to ensure the coverage and participation of educational activities and to enhance the attractiveness and effectiveness of education. Even for the same event, the national humiliation education in colleges and universities should reflect their respective characteristics, such as highlighting academic, exploratory and speculative features, and avoiding simple repetition of same contents and methods.

\subsection{Pay Attention to Curriculum Education and Play the Role of Main Channel}

First of all, from the level of teaching ideological and political courses, national humiliation education should not only rely on the outline course of modern Chinese history, but also include all other ideological and political courses, such as Situation and Policy, Basic Principles of Marxism, etc., reflecting national humiliation education in the teaching process. For example, the military theory class can combine "the strong ships and powerful guns of imperialism" with China's history of weapons research and manufacturing, courses related to aircraft strength and structure can take "the Sino-US South China Sea Crash" as a case study, and international law courses can also analyse "the U.S. missile attack on our embassy in Yugoslavia" and other events so as to achieve the same direction of national humiliation education in all courses.

\subsection{Cohesion and Optimization of the Educational Environment}

First, we should pay attention to the protection and development of national humiliation sites, and provide high-quality sites and resources for national humiliation education by salvaging people who have lived through national humiliation events and their information through video and audio, documentaries, biographies and memoirs. Second, we should make use of modern means of communication to popularize the historical facts of aggression suffered by our country since modern times globally, so as to gain moral recognition, emotional sympathy and public opinion support from more countries, international organizations and people with a sense of justice, and also to create a good atmosphere for colleges and universities to carry out national humiliation education in a straightforward manner. Third, in view of the current phenomenon that 
the sense of humiliation in society is gradually diluted, efforts should be made to strengthen the education advocating the socialist concept of honour and disgrace, to guide college students to judge right and wrong, know honour and humiliation, distinguish good and evil, and distinguish beauty and ugliness, to enhance the concept of national humiliation among college students, and to strengthen their determination and confidence to study diligently, serve the country and achieve national rejuvenation.

\section{CONCLUSION}

National humiliation education is an important part of patriotism education and should be one of the key points of Ideological and political work in universities. Through the analysis of the effective ways of carrying out national humiliation education in foreign countries, such as reviewing the history, recalling the ancestors, using the ruins, carrying out the national sacrifice and so on, aiming at the weak links existing in the current work of universities in our country, such as the uneven sense of national humiliation, the weak pertinence of education effectiveness, the low participation of educational activities, the increasingly complex educational environment and so on, this paper proposes to strengthen the evaluation and supervision, enhance the quality of education Dialectical thinking, solidifying the carrier of education, enhancing the attractiveness, paying attention to curriculum education and optimizing the educational environment are six comprehensive improvement measures, which will help to strengthen and improve the ideological and political work in universities, and cultivate more new people to undertake the task of national rejuvenation.

\section{AUTHORS' CONTRIBUTIONS}

This paper and related research have been completed by the author himself under the guidance of his tutor.

\section{ACKNOWLEDGMENTS}

This research is supported by the key project of Ideological and political work for students in NPU in 2020.

Thanks to Professor Zhoulu Xiao for his guidance during the process of research and the writing of this paper.

\section{REFERENCES}

[1] Li Hajuan. Research on national humiliation education in the early days of the founding of the Communist Party of China. Zhejiang Agriculture and Forestry University,2014.

[2] Outline of the implementation of patriotism education in the new era. People's Publishing House, 2019, 978-7-01-021548-8

[3] Selected works of Marx and Engels. Vol. 1. People's Publishing House, 1995: p, 9. ISBN: 9787-01-010686-1

[4] Chen Zhen, Li Peng. A glimpse of foreign national humiliation education. National Defense, 2007, pp, DOI:32-33.10.3969/j.issn.1002-4484.2007.05.012

[5] Zhang Yihong. The rise and development of national humiliation education in schools in the early Republic of China. Guangxi Social Science, 2006, pp, 192-194. DOI:10.3969/j.issn.10046917.2006 .12 .051 